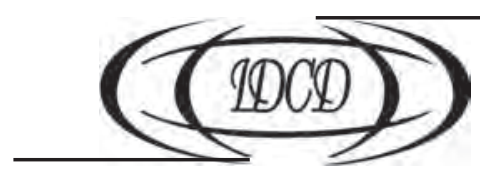

doi: $10.15407 /$ dse2016.03.034

УДК $314.8 ; 314.7 ; 330.33$ (477)

JEL Classification: E24, E29, R23, O15, O33

\title{
О.Г. РОГОЖИН
}

д-р екон. наук, старш. наук. співроб., голов. наук. співроб.

Інститут телекомунікацій та глобального інформаційного простору НАН України

03186, Україна, м. Київ, Чоколівський бул., 13

E-mail: olexarog@gmail.com

\section{ОЦІНКА ПОТЕНЦІЙНИХ ВТРАТ НАСЕЛЕННЯ УКРАЇНИ: МАКРОЕКОНОМІЧНИЙ ПІДХІД}

Для оцінки потенційних демографічних втрат населення сучасної України реалізовано макроекономічний підхід, оскільки фундаментальною причиною суспільно-політичних катастроф, пов'язаних зі значними демографічними втратами, є макроекономічний фактор. Цей фактор виявляє себе як демографічна ємність національної економіки. Ми коротко визначили таку ємність терміном «демоекономічна ніша».

Обгрунтовано індекси, за допомогою яких можна оцінити «моментний» (річний) потенціал зменшення всього $i$, зокрема, сільського населення. Потенційні демографічні втрати всього населення оцінені як співвідношення середньодушового рівня сукупних ресурсів домогосподарств та офіційного прожиткового мінімуму, виміряних у \$ ПКС 2004 р. (в паритеті купівельної спроможності 2004 року) із врахуванням інфляції (індекса споживчих цін) і коефіцієнта ціни репродукції населення. Потенційні демографічні втрати сільського населення - як співвідношення середньодушових рівнів сукупних ресурсів сільських домогосподарств та валової продукції аграрного сектора, виміряних у поточному \$ ПКС.

Згідно з розрахунками щодо всього населення, в 1999-2008 рр. відбувалися квазіциклічні коливання демоекономічного потенціалу зменшення всього населення на рівні 5-6 млн осіб. Потім виникла тенденція до його поступового збільшення зі стабілізацією на рівні 14-15 млн. У 2014 р. сталося стрімке зростання потенціалу втрат всього населення до понад 20 млн осіб. Динаміка потенціалу втрат сільського населення від'ємна. Він скоротився від рівня у понад 8 млн в 2000-2001 рр. до менш ніж 1 млн в 2009 р. Потім відбувся злам тенденції, у 2014 р. потенціал зменшення сільського населення досяг 5 млн осіб.

Макроекономічна оцінка потенціалу «моментних демографічних втрат відображає лише можливість їх здійснення. Інші чинники можуть або перешкоджати, або сприяти реалізації потенціалу.

Ключові слова: населення, споживання, рівень доходів (сукупних ресурсів), соціальні стандарти, прожитковий мінімум, демографічна ємність національної економіки, зменшення демоекономічної ніші, потенційні демографічні втрати.

\section{А.Г. Рогожин}

д-р. экон. наук, старш. науч. сотруд., глав. науч. сотруд.

Институт телекоммуникаций и глобального информационного пространства

03186, Украина, г. Киев, Чоколовский бул., 13

E-mail: olexarog@gmail.com

(с) РОГОЖИН О.Г., 2016 


\section{ОЦЕНКА ПОТЕНЦИАЛЬНЫХ ПОТЕРЬ НАСЕЛЕНИЯ В УКРАИНЕ: МАКРОЭКОНОМИЧЕСКИЙ ПОДХОД}

Для оценки потенциальных демографических потерь населения современной Украины реализован макроэкономический подход, поскольку фундаментальной причиной общественно-политических катастроф, связанных со значительными демографическими потерями, служит макроэкономический фактор. Этот фактор обнаруживает себя как демографическая емкость национальной экономики. Мы коротко определили такую емкость термином «демоэкономическая ниша».

Определены индексы, с помощью которых можно оценить «моментный» (годовой) потенциал уменьшения всего и, в частности, сельского населения. Потенциальные демографические потери всего населения оценены соотношением среднедушевого уровня совокупных ресурсов домохозяйств и официального прожиточного минимума, измеренных в \$ ПКС на 2004 г. (в паритете покупательной способности 2004 г.) с учетом инфляции (индекса потребительских иен) и коэффициента иены репродукции населения. Потенциальные демографические потери сельского населения - соотношением среднедушевых уровней совокупных ресурсов сельских домохозяйств и валовой продукции аграрного сектора, измеренных в текущем \$ ПКС.

Расчеты показали, что в 1999-2008гг. происходили квазициклические колебания демоэкономического потенциала уменьшения всего населения на уровне 5-6 млн чел. Потом возникла тендениия к его постепенному увеличению со стабилизацией на уровне 14-15 млн. В 2014 г. произошел стремительный рост потенциала потерь всего населения до свыше 20 млн чел. Динамика потенциала потерь сельского населения иная. Он сократился от уровня свыше 8млн в 2000-2001 г2. до менее чем 1 млн в 2009г. Потом произошла смена тенденции, в 2014 г. потенциал уменьшения сельского населения достиг 5 млн чел.

Макроэкономическая оценка потенциала «моментных» демографических потерь отображает лишь возможность их осуществления. Другие факторы могут или препятствовать, или способствовать реализации потенциала.

Ключевые слова: население, потребление, уровень доходов (совокупных ресурсов), социальные стандарты, прожиточный минимум, демографическая емкость национальной экономики, сокращение демоэкономической ниши, потенциальные демографические потери.

\section{O.G. Rogozhin}

Dr. Sc. (Economics), Senior Scientist

Institute of Telecommunications and Global Information Space

of the National Academy of Sciences of Ukraine

03186, Ukraine, Kyiv, 13 Chokolovsky blvd.

E-mail: olexarog@gmail.com

\section{AN ESTIMATION OF POTENTIAL DEMOGRAPHIC LOSSES IN UKRAINE: THE MACROECONOMIC APPROACH}

The macroeconomic approach is realized for the estimation of potential demographic losses of present Ukrainian population. Because the fundamental reason of social and political catastrophes connected with considerable demographic losses is a macroeconomic factor. This factor reveals itself as the national economy demographic capacity. We determined this capacity with the short term «demoeconomic niche».

The indexes with which it is possible to estimate «momental» (annual) potential of diminishing the whole and in particular rural population are substantiated. Potential demographic losses (diminishing of whole population) are represented with the ratio of per capita value of aggregate whole household resources and the official minimum subsistence level, measured in 2004 \$PPP taking in account inflation (CPI) and reproduction cost coefficient. Potential demographic losses of rural population - with the ratio of per capita value of aggregate rural household resources and per capita output of agrarian sector, measured in current \$PPP.

In accordance with calculations for whole population, in 1999-2008 there were quasi-cyclic fluctuations of the potential size of whole population losses measuring 5-6 million. Then formed a tendency of its gradual increase of whole population potential losses with its stabilization at the level of 14-15 millions, but in 2014 a sharp growth to over 20 million occurred. Dynamics of rural population potential losses is different. It diminished from a size of over 8 millions in 2000-2001 to less than 1 million in 2009. Then the tendency had changed. In 2014 the demoeconomic potential of Ukrainian rural population losses is estimated in approximately 5 million persons. 
The estimation of macroeconomic potential of «momental» demographic losses is only a possibility of their realization. Other factors can both prevent or facilitate them.

Keywords: population, consumption, income behavior, social standards, minimum subsistence level, national economy demographic capacity, reduction of demoeconomic niche, potential demographic losses.

Постановка проблеми та актуальність обраної теми. Зміни кількості населення та пов'язані з цим міграційні рухи істотно впливають на розвиток національних економік у середньо- та довготерміновій перспективі. У світі завжди існували країни, які періодично «викидали» значну частину свого населення за кордон в якості емігрантів та гастарбайртерів. Давно встановлено, що демографічні ефекти є значною мірою похідними від економічних механізмів циклічної динаміки коливання доходів та витрат у структурному розподілі по країнах і групах населення в масштабі національних економік.

Проблема подолання економічно обумовленої депопуляції особливо актуальна в Україні, яка кілька разів протягом новітньої історії ставала, і сьогодні є, країною активної трудової еміграції, втрачаючи активну, фізично здорову, освічену і інтелектуально розвинену частину свого населення.

Цьому сприяє те, що «транзитивна» економіка України сьогодні є малою, відкритою, сировинно експортно орієнтованою, до того ж, відбувається іiі аграризація. У 2015 р. на перше місце в українському товарному експорті вийшла сільськогосподарська продукція (38 \%) за збереження великої частки металургійної (24,8 \%). У першому кварталі 2016 р. частка аграрного експорту досягла $43 \%$, хоч у структурі ВВП сільське господарство має набагато меншу питому вагу $-12 \%[1,2]$.

Ціни на будь-яку сировину відзначаються підвищеною мінливістю залежно від змін світової кон'юнктури. В кризові періоди вони зазнають різкого і тривалого зниження. Крім того, будь яка сировина належить до товарів із низькою доданою вартістю і низькою ціною одиниці продукції, що компенсується великими обсягами виробництва, яке є енерговитратним і матеріаломістким. Нарощування випуску сировини і напівфабрикатів супроводжується випереджувальним зростанням виробничих витрат, особливо у випадку сільськогосподарського виробництва. Тому важко очікувати збільшення доходів від аграрного експорту з України понад досягнутий рівень у \$10-12 млрд.

За усе більшої рентабельності українських агровиробників ефективність аграрного експорту є примарною, оскільки його імпортна складова (машини, матеріали, пальне тощо) становить $72 \%$, оплата праці - $10 \%$ і лише $8 \%$ - чистий дохід (до $\$ 1$ млрд) [3]. Це недостатній фінансовий ресурс для розвитку країни, сировинний характер економіки протирічить потребі досягнення стійкого економічного зростання, приросту доходів населення, подоланню безробіття і бідності. Особливо на фоні від’ємного природного приросту, активної трудової міграції, швидкої втрати людського й інтелектуального капіталів, постаріння населення, що збільшує навантаження на доходи працівників.

Все це посилює необхідність здійснення обгрунтованих оцінок соціально-демографічних наслідків затяжних кризових процесів в Україні з метою інформаційної підтримки політичних рішень щодо поліпшення ситуації. Це актуалізує питання удосконалення методології оцінки впливу економічних факторів на демографічні процеси.

Ступінь дослідження проблеми та аналіз останніх досліджень. Економіко-демографічні дослідження були започатковані ще класиками англійської політичної еконо- 
мії У. Петті (U. Petty), А. Смітом (А. Smith), Т. Мальтусом (Т. Mal'thus), Д. Рікардо (D. Ricardo), Дж. Міллем (Dj. Mill). В рамках класичної економічної теорії T. Мальтус обгрунтував «залізний закон заробітної плати», згідно з яким стабільна рівновага чисельності населення підтримується природним рівнем фонду оплати праці (доходами населення), який забезпечує робітникам фізично необхідний мінімум засобів існування (прожитковий мінімум). Т. Мальтус, Ф. Лассаль, Д. Рікардо «залізний закон заробітної плати» виводили зі збільшення народонаселення, К. Маркс пов'язав його зі зростанням органічної побудови капіталу і перерозподілом доходів на користь власників засобів виробництва.

Пізніше кембриджська школа маржиналізму (А. Маршалл (А. Marshall), А. Пігу (A. Pigou), П. Самуельсон (P. Samuelson) та інші) розглядала заробітну плату як ціну одного із факторів виробництва, що визначається «граничним» продуктом - додатковим випуском продукції при використанні додаткової одиниці праці. Обгрунтоване ними визначення ціни праці її продуктивністю (корисністю) стало загальновизнаним. Дж. M. Кейнс (D.M. Keynes) акцентував увагу на нееластичності заробітної плати (основи доходів домогосподарств) до впливу знижувальних тенденцій та на залежності ставок зарплати від неринкових, соціально-політичних факторів. Згідно з цим прихильники інституціоналізму висунули концепцію «договірної зарплати».

Врахувавши доробок попередників, сучасна неокласична теорія визначила заробітну плату як результат ринкової взаємодії попиту та пропозиції плюс стану соціально-політичних досягнень. За пояснення економічного механізму підтримання низької народжуваності в розвинених країнах на основі неокласичних передумов Г. Беккер отримав Нобелівську премію (1992 р.).

В Україні економіко-демографічні дослідження започаткувала В.С. Стешенко (V.S. Steshenko). Їх продовжили C.I. Пірожков (S.I. Pyrozhkov), Е.M. Лібанова (E.M. Libanova), О.У. Хомра (O.U. Нотra), О.А. Малиновська (O.A. Malinovs'ka), O.B. Позняк (O.V. Poznyak), М.Д. Романюк (M.D. Romanyuk), В.П. Кузьменко (V.P. Kuz'menko), I.П. Макаренко (I.P. Makarenko) та інші.

Дослідження впливу економічного фактору на зміни чисельності населення набули розвитку передусім у рамках теорій міграції як найбільш однозначного наслідку економічної динаміки. Згідно з ними масові переселення людей виникають тільки через гостру необхідність, причому уся сукупність причин міграції належить до економічних, демографічних, природно-кліматичних, політичних та соціальних чинників [4]. Узагальнення сукупності факторів, що спричиняють міграції, здійснене, зокрема, в роботах В.І. Перевєдєнцева [5]. Економічні чинники вважаються провідними не лише для трудової міграції. У формі кризових явищ в економіці, що супроводжуються спадом виробництва, зростанням інфляції, безробіття, вони призводять до зниження рівня життя і занепаду соціальної сфери. Фундаментальною основою для активізації всіх факторів сприяння міграції $€$ кризовий стан економіки, оскільки саме постійне зниження рівня і якості життя призводить до підвищення міграційної активності.

Одна з класифікацій теорій міграції населення поділяє їх на дві групи: міграційні теорії рівноваги та просторово-тимчасові «транзитивні» теорії міграції. До першої групи належать моделі факторів «виштовхування» і «притягання», а також неокласична теорія міграції. До другої - просторово-тимчасова і просторова теорії міграції та теорія міграційного підйому [6]. Згідно з неокласичною теорією, процес трудової міграції на макрорівні є результатом різниці між попитом і пропозицією праці та різниці в доходах, коли працівники мігрують із регіонів з низьким рівнем 
заробітної плати і надлишковою робочою силою до регіонів з високою заробітною платою і дефіцитом трудових ресурсів [7].

Нова економічна теорія міграції акцентує увагу на недосконалості ринків, ознаками чого є: відсутність достатнього медичного страхування, високі відсоткові ставки по кредитах, недосконалість державного регулювання приватного бізнесу, труднощі заощадження через нерозвиненість фінансових інститутів, тощо [8]. Зрозуміло, що найменш досконалими є ринки в країнах, що розвиваються, зокрема, у «транзитивних» пострадянських економіках.

Спробою розробити єдиний підхід до аналізу міжнародної міграції стала синтетична теорія міграції, що також зосереджена переважно на їі економічних чинниках [9, с. 143].

Основними елементами мотиваційної структури міграційних процесів вважається реакція населення на кризовий стан економіки і суспільства у таких формах: втеча від злиднів та незайнятості; підвищення рівня життя шляхом отримання більшої суми заробітку; намагання уникнути збройних конфліктів і воєн; втеча від політичних переслідувань і міжетнічних сутичок; втеча від екологічних і техногенних криз чи катастроф [10, 11].

Грунтовний аналіз макроекономічних передумов виникнення гуманітарних катастроф, зокрема голоду, в періоди соціально-економічних криз у контексті єволюції економічних систем здійснив І.П. Макаренко [12].

3 огляду на новизну і перспективність такого підходу за теперішнього глобального посилення соціально-економічної нестабільності, метою нашого дослідження $є$ оцінка потенціалу демографічних втрат населення сучасної України, зумовлених можливим поглибленням кризових процесів в її економіці та соціальній сфері.

Виклад основного матеріалу. В центрі економічного аналізу зазвичай перебуває чисельність населення та темпи їі приросту як фактори, що можуть справляти тиск на обмежені ресурси, призводити до зменшення відношення капіталу до праці або до економії на масштабах виробництва [13, с. 8].

Однак зворотний вплив економічного фактора на відтворення населення ні в економетричних, ні в макроекономічних моделях у явній формі не враховується, незважаючи на те, що саме цей вплив, на нашу думку, формує фундаментальне демоекономічне обмеження, рамкове для процесів міграції та відтворення населення в національних економіках.

Теоретико-методологічний напрям демоекономічних досліджень орієнтований на визначення тих економічних показників, від яких безпосередньо залежать і які безпосередньо спричиняють зміни кількості і якості населення, в першу чергу - режимів природного і міграційного руху населення у їхніх демостатистичних наслідках, як коротко-, так і довгострокових. Такі показники досліджуються в рамках соціологічної парадигми «людського розвитку» і концепції «якості життя».

Базовим компонентом якості життя є категорія «рівень життя», що інтерпретується як ступінь економічного добробуту за інтегральними характеристиками доходів, споживання, вартості життя [14, с. 10-11]. Саме наявний дохід є основним економічним фактором, що забезпечує кінцеве споживання домогосподарств. Причому в усіх країнах світу доходи основної маси домогосподарств економічно активного населення (маси трудящих) в середньому більше ніж на 80 \% складаються з заробітної плати. Зрозуміло, що рівень реальних доходів домогосподарств набуває соціального і демоекономічного значення у співвідношенні з комплексним показником вартості життя (ціною підтримання життєдіяльності людини та відновлення її працездатності 
в конкретних історичних умовах певного рівня розвитку національної та світової економік, суспільної організації та зовнішніх загроз), пов’язаним з інтегральною ознакою якості життя. Чим більшою стає додатня різниця між ними, тим виразніше діє фактор, який збільшує потенціал (притягальність) економічної імміграції з регіонів (і країн), де така різниця від’ємна або помітно менша. Цим також створюється економічний потенціал для зростання тривалості життя і реалізації репродуктивних установок щодо дітонародження, а також, у довшій перспективі, для їхньої модифікаці.

Вивчаючи перманентні кризові процеси в сучасній Україні [15], автор переконався у перспективності макроекономічного підходу для визначення показників оцінки масштабів потенційних демографічних втрат. Оскільки фундаментальною першопричиною соціально-політичних катастроф, пов'язаних зі значними демографічними втратами, був і є саме макроекономічний фактор. Він матеріалізується у формі демографічної ємності національної економіки, як її здатність забезпечити життєдіяльність певної кількості населення за певних економіко-географічних і техніко-економічних умов розвитку та соціальних стандартів його життєдіяльності. Для стислого визначення цієї категорії автор запропонував термін «демоекономічна ніша», що є соціально-економічною інтерпретацією біологічного поняття «екологічна ніша».

Зазначені демоекономічні ніші можуть як розширюватись, притягаючи до себе демографічні ресурси (не лише робочу силу), так і звужуватись, «витискаючи» за межі національних (і регіональних) економік «зайву» й водночас найбільш мобільну частину населення. Причому соціальні збурення з наступними політичними катаклізмами залежать від величини та темпу зменшення демографічної ємності економіки, тобто їм або передує, або їх супроводжує значне скорочення демоекономічної ніші.

За всіх можливих відхилень, у сучасній технічній цивілізації спостерігається еволюційна тенденція до збільшення вартості життя із розвитком виробничих сил, пов’язана з диверсифікацією та якісним удосконаленням потреб населення. Відповідно, якщо темпи приросту доходів населення відстають від темпів приросту вартості життя, в країнах імміграції пригнічуються процеси природного відтворення корінного населення за тривалого припливу гастарбайртерів з бідних країн і аграрних регіонів, де доходи і вартість життя значно менші.

Тому саме вартість життя ми розглядаємо як основний соціальний стандарт національної економіки, який у співвідношенні з рівнем середньодушового доходу домогосподарств, залежним від ціни праці, формує демоекономічний стандарт, визначаючи характер міграційного і природного руху населення. Ми розуміємо під таким стандартом не «демографічний оптимум» для національної економіки, а середньодушовий рівень споживання (витрат), на який у своєму індивідуальному споживанні орієнтується переважна маса населення, вважаючи його теоретично достатнім для повноцінного життя (включно із сумою, необхідною для повної реалізації наявних історично конкретних демографічних установок щодо дітонародження) [16].

Відповідно ємність демоекономічної ніші визначається співвідношенням двох величин: середньодушового доходу домогосподарств $(Y h)$ і мінімального стандарту середньодушових витрат $(C s)$. Причому цей стандарт історично, соціально і культурно обумовлений та еволюціонує у бік збільшення залежно від рівня розвитку не тільки національної, а й світової економіки. Крім поточного споживання для фізичного, інтелектуального і духовного відтворення населення, домогосподарства через відповідні податки мають брати участь у відтворенні загальнонаціональної інфраструктури, зокрема наукової та навчальної бази. Відповідно, рівень доходів домогосподарств має покривати всі ці потреби (з урахуванням заощаджень). 
Установлено, що серед усіх змінних і функцій, використаних у макроекономічних моделях, саме параметр автономного споживання домогосподарств на душу населення ( $C a-$ із кейнсіанської функції споживання) найкраще відображає мінімальний рівень вартості життя як основний соціально-економічний стандарт для певних національних економік у визначений період часу. Він ототожнюється з реальним рівнем нижньої межі бідності (малозабезпеченості), а рівноважний рівень доходів і споживання (неможливість здійснювати заощадження) - з реальним рівнем верхньої межі бідності.

Зазначені стандарти можуть бути незмінними лише в періоди економічної стабільності. В періоди соціально-економічної нестабільності актуалізується потреба в моментних, рік до року, оцінках. На рівень автономного споживання впливають: обсяг активів домогосподарств, очікування надходжень через успадкування, рівень довіри в суспільстві, тривале зростання або зменшення добробуту, наявність суспільної угоди щодо мінімально прийнятних соціальних стандартів.

Причому рівень автономного споживання не враховує витрат на демовідтворення, тобто до нього має бути додана ціна репродукції населення на рівні простого заміщення поколінь, наприклад, у вигляді відповідного підвищувального коефіцієнта. Тобто необхідно використовувати значення демографічно ефективного рівня автономного споживання.

3 наведених міркувань може бути виведений базовий параметр, що визначає потенціал скорочення або збільшення кількості населення у рік $i$. Він набуває аналітичної форми $\Delta_{i}=\frac{Y r_{i}}{k \cdot C a_{i}}$, де для умов України величина середньодушових доходів найкраще апроксимується показником сукупних ресурсів домогосподарств $\left(\boldsymbol{r}_{i}\right)$, а коефіцієнт репродукції населення становить $k=1,145$ [16, с. 36].

Відповідно, демоекономічний потенціал (тобто ємність економіки) у рік $i$ становитиме $P_{a}=P_{i} \cdot \Delta_{i}$, де $P_{i}-$ кількість населення у рік $i$.

Це дає змогу розрахувати максимальну оцінку (потенційно) можливого зменшення населення у рік $i$ за рахунок трудової міграції-еміграції та скорочення природного приросту:

$$
P \Delta_{i}=P_{i} \frac{Y r_{i}}{k \cdot C a_{i}}-P_{i} .
$$

Виникає питання про макроекономічні передумови, які забезпечують демовідтворення у довгостроковій перспективі. Вони теоретично визначаються на основі класичного економічного інструментарію (агрегованої виробничої функції по капіталу). Умовами стійкої репродукції автохтонного населення є додатній приріст граничного продукту капіталу (приріст доходності на одиницю подальших вкладень капіталу), приріст або стабільність автономного споживання домогосподарств (з урахуванням ціни репродукціï) та додатня різниця цих приростів. Умовою приваблення емігрантів із бідніших країн - додатній приріст граничного продукту капіталу, приріст або стабільність автономного споживання та від'ємна різниця цих приростів. Умовою стійкого зменшення ємності демоекономічної ніші є зменшення граничного продукту капіталу, зменшення або стабільність автономного споживання та від'ємна різниця цих приростів. На жаль, визначити граничний продукт капіталу національної економіки без спеціальних досліджень досі неможливо через відсутність надійних методів розрахунку агрегованої виробничої функції. 
Рівень автономного споживання домогосподарств також безпосередньо не відображений статистикою. Показники для його відображення доводиться емпірично підбирати для кожної конкретної економіки з тих, що є в наявності, за критерієм найкращої відповідності траекторіям економічної динаміки, динаміки реальних доходів та споживання населення.

Згідно з результатами наших розрахунків, рівень демографічно ефективного автономного споживання домогосподарств для всього населення в умовах України найкраще апроксимується показником законодавчо встановленого прожиткового мінімумуму на 2004 р., виміряного у \$ПКС із урахуванням інфляції та коефіцієнта репродукції населення $\left(C_{\min 2004}\right)$. Через те, що саме 2004 року була досягнута рівність сукупних ресурсів і витрат населення в Україні.

Однак для сільської місцевості цей показник виявився непридатним. На нашу думку, через те, що доходи сільського населення України переважно генеруються в аграрному секторі економіки, зокрема у особистих селянських господарствах (ОСГ) зі значною часткою натуральних розрахунків, не відображених статистичним обліком. Тому показником, що найкраще відобразив рівень демографічно ефективного автономного споживання сільського населення, виявилася середньодушова (на одиницю сільського населення) продукція аграрного сектора у поточному $\$$ ПС $\left(Q_{a g}\right)$.

Розрахунок «моментної» прогнозної оцінки потенційних демографічних втрат для всього населення України у період 1999-2014 рр. здійснено за формулою (1) із використанням показника $C_{\text {мінгео4 }}$ для відображення рівня його автономного споживання. Така оцінка демонструє нелінійну динаміку значень: до 2001 р. - зростання потенціалу втрат до -12 млн осіб, потім - його зменшення аж до появи потенціалу зростання населення у 2005-2006 рр., по тому - нове зростання потенціалу демографічних втрат із стабілізацією на рівні -14: -16 млн осіб у 2012-2013 pр., нарешті його різке збільшення до майже -23 млн осіб у 2014 р. (рис. 1).

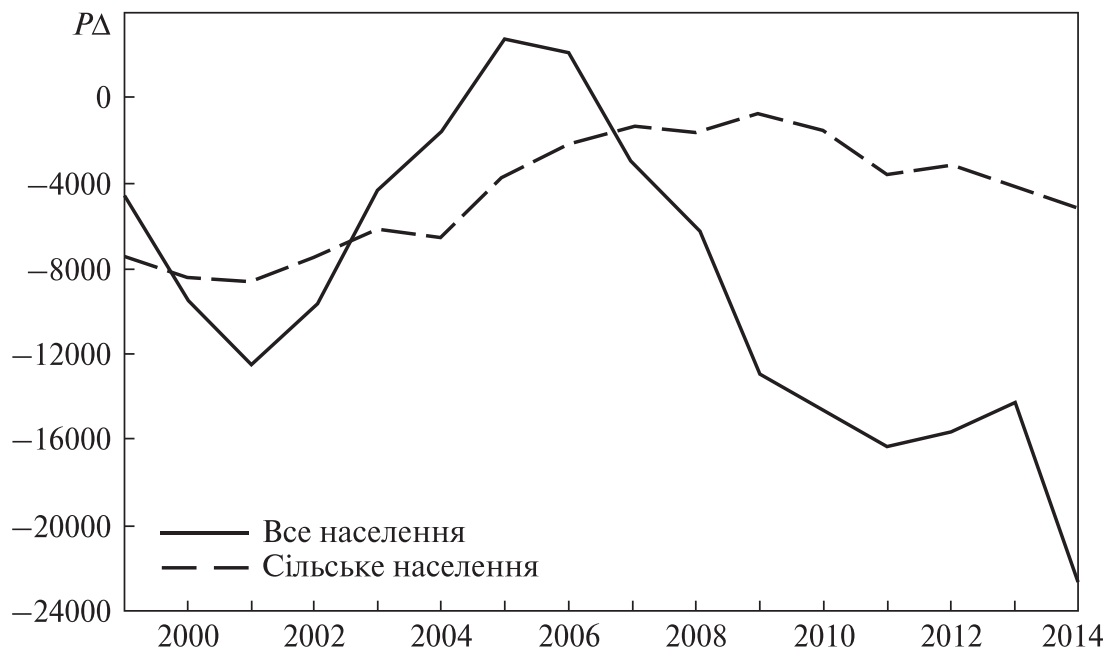

Puc. 1. Динаміка «моментного» потенціалу втрат всього і сільського населення України у 1999-2014 pp.

Джерело: авторські розрахунки на основі даних Держстата України та Світового Банку. 


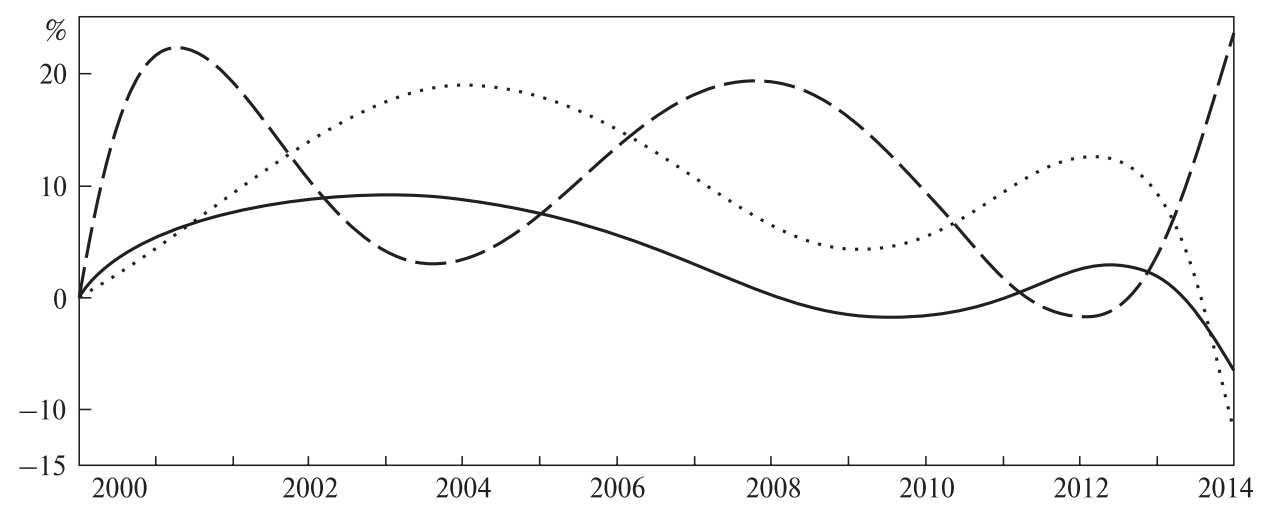

Поліноміальний тренд прироста ВВП ( $\triangle G D P, \%$ рік до року)

$$
\begin{aligned}
\Delta G D R & =-0,0002 x^{6}+0,0106 x^{5}-0,1826 x^{4}-1,5389 x^{3}+7,0843 x^{2}+18,121 x-12,203 \\
R^{2} & =0,5065
\end{aligned}
$$

…… Поліноміальний тренд прироста наявного доходу всього населення ( $\Delta Y r, \%$ рік до року)

$$
\begin{aligned}
& \Delta Y r=-0,0003 x^{6}+0,0119 x^{5}-0,162 x^{4}-0,8906 x^{3}+2,1328 x^{2}+6,6839 x-5,1955 \\
& R^{2}=0,6464
\end{aligned}
$$

- - Поліноміальний тренд прироста демографічно ефективного рівня автономного споживання, відображеного показником $\Delta C_{\text {min }} 2004$ * $k$, (\% до рівня 1999 р.), де

$k$ - ціна репродукції населення

$\Delta C_{\min } 2004 * k=-0,0005 x^{6}+0,0319 x^{5}-0,7631 x^{4}-8,6444 x^{3}+47,452 x^{2}+113,96 x-74,565$

$$
R^{2}=0,8573
$$

Рис. 2. Циклічні коливання приросту демографічно ефективного рівня автономного споживання в Україні у протифазі з коливаннями прироста доходів населення та ВВП (1999-2014 рр.)

Джерело: авторські розрахунки на основі даних Держстата України та Світового Банку.

Зменшення потенціалу втрат усього населення відбувалося завдяки перевищенню приросту середньодушових доходів (сукупних ресурсів) над приростом соціального стандарту демографічно ефективних витрат (демографічно ефективного рівня автономного споживання). А збільшення потенціалу втрат - у зворотному випадку, через гальмування приросту середньодушових доходів внаслідок посилення кризових явищ в українській економіці. Причому приріст середньодушових доходів корелює з економічною динамікою (приростом ВВП), рис. 2.

Український соціальний стандарт споживання зростав практично весь період спостереження (рис. 3), поступово наближаючись до такого у розвинених країнах Європи як сучасного цивілізаційного ідеала. Прискоренню його поширення сприяло безмежне «статусне» споживання вузького прошарку скоробагатьків і пов'язаної з ними вищої бюрократії. Сформовані ними неегалітарні інститути не сприяють створенню умов для відновлення стійкого економічного зростання, гальмуючи інноваційні процеси, структурні перетворення і соціальний розвиток через різко асиметричний розподіл доходів. На жаль, единими способами для заміни цих «поганих» інститутів на егалітарні («хороші») є соціальна революція або радикальне реформування під тиском екстремальних зовнішніх обставин [17].

Для сільського населення ситуація виглядає складнішою, за період спостереження 1999-2014 pр. жодного року не зафіксовано потенціал додатнього приросту. Розрахунок також здійснено за формулою (1), але з використанням показника $Q_{a g}$ для відображення рівня автономного споживання сільського населення. 


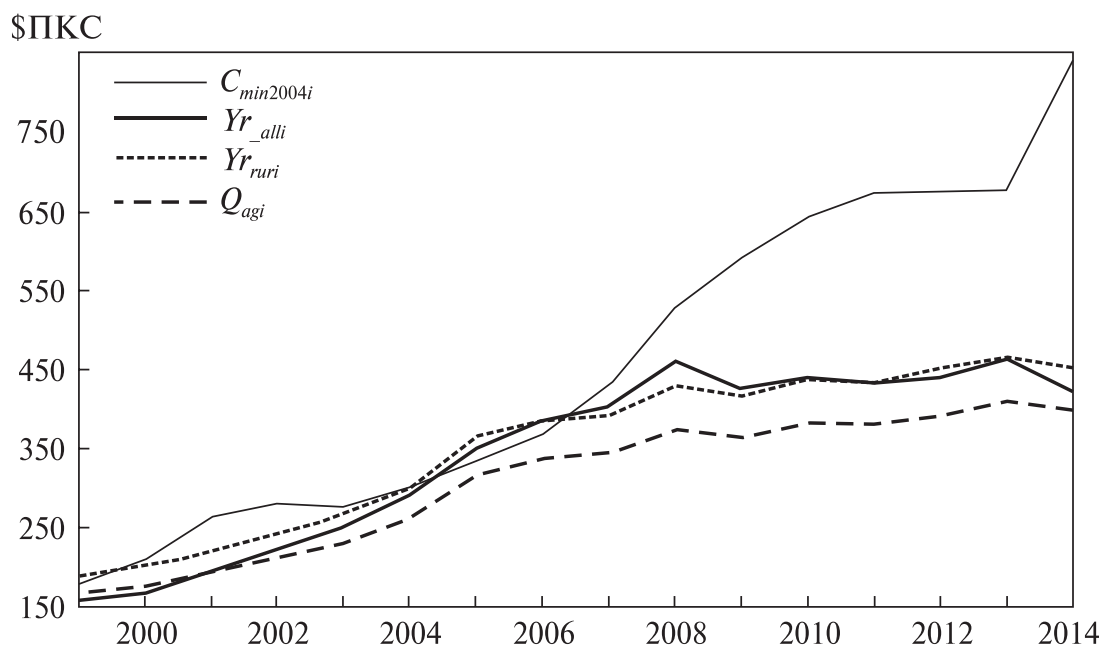

Рис. 3. Динаміка демографічно ефективних середньодушових соціальних стандартів споживання та сумарних ресурсів всього і сільського населення України у 1999-2014 рр.

Джерело: авторські розрахунки на основі даних Держстата України та Світового Банку.

Динаміка «моментної» оцінки потенціалу зменшення сільського населення помітно відрізняється від такої для всього населення України. Для сільської місцевості спостерігалися періоди: збільшення потенціалу демографічних втрат у 1999-2001 pp. до рівня у понад -8 млн осіб, потім його тривале зменшення до рівня $-0,8$ млн осіб у 2007 рр., стабілізація наступного року із невеликим зменшенням у 2009 р. (до $-0,6$ млн), потім - нове зростання потенціалу демографічних втрат до рівня -5 млн осіб у 2014 р. (із короткочасною стабілізацією в 2012 р.), рис. 1.

Указані відмінності обумовленні значно нижчою оплатою праці у низькоукладному аграрному секторі України, обтяженому мільйонами технічно відсталих і малоприбуткових ОСГ, порівняно з промисловим виробництвом та сферою послуг.

Зрозуміло, що наведена оцінка «моментних» демографічних втрат є лише можливістю їх реалізації за додаткових умов, які можуть як стримувати (наприклад, закриття кордонів за відсутності загрози фізичного вимирання населення), так і сприяти їм (масштабні бойові дії, розруха, природні катастрофи).

\section{Висновки}

1. Для оцінки рівня потенційних демографічних втрат населення в сучасний період доцільно застосовувати макроекономічний підхід. Оскільки фундаментальною причиною значного і тривалого міграційного відпливу та/або від’ємного відтворення населення є макроекономічний фактор.

2. Макроекономічний фактор зменшення населення реалізується у формі демографічної ємності національної економіки, для стислого визначення якої введено термін «демоекономічна ніша». Соціальні і політичні збурення безпосередньо залежать від величини та темпу зменшення демографічної ємності економіки (скорочення демоекономічної ніші).

3. «Моментний» потенціал демографічних втрат всього населення відображається відношенням середньодушової вартості сукупних ресурсів домогосподарств і офіційного прожиткового мінімуму, виміряних у паритеті купівельної спроможності (\$ПКС) на 2004 р. із врахуванням інфляції (ІСЦ) та ціни репродукції. Потенціал 
втрат сільського населення - відношенням середньодушової вартості сукупних ресурсів сільських домогосподарств і середньодушової продукції аграрного сектора (в поточному \$ПКС) як демографічно ефективного рівня автономного споживання сільського населення.

4. За розрахунками для всього населення України у 1999-2008 рр. відбувалися квазіциклічні коливання «моментної» оцінки демографічних втрат навколо потенційної величини у 5-6 млн осіб, потім сформувалася тенденція до поступового збільшення потенціалу втрат зі стабілізацією його на рівні 14-15 млн, а у 2014 р. сталося різке зростання потенціалу втрат до понад 20 млн осіб.

5. Динаміка «моментної» оцінки потенційних втрат сільського населення дещо відрізняється - зменшення від рівня у понад 8 млн (2000-2001 рр.) до менше 1 млн у 2009 р., потім - злам тенденції та зростання потенціалу втрат. У 2014 р. демоекономічний потенціал втрат сільського населення України оцінювався величиною в приблизно 5 млн осіб.

6. Необхідною умовою мінімізації економічно обумовленого потенціалу демографічних втрат є випереджувальне збільшення реальних середньодушових доходів населення (з урахуванням інфляціі). Їх може принести тільки тривале економічне зростання, яке не здатні забезпечити традиційні, базові галузі економіки, зокрема аграрний сектор.

7. Розірвати порочне коло стагнації, бідності і занепаду взмозі лише запуск системних інноваційних процесів із формуванням потужного інноваційного сектору, як це було здійснено, наприклад, у Південній Кореї. Але це потребуватиме створення фінансового атрактора - поєднання безпекових, інституційних і макроекономічних умов, сприятливих для припливу капіталів.

\section{ЛІТЕРАТУРА}

1. Украина все больше превращается в аграрную страну [Електронний ресурс]. - Режим доступу: http://iee.org.ua/ru/prog_info/35382/

2. Павленко O. Український агросектор на шляху реформ: здобутки та перспективи [Електронний ресурс] - Режим доступу: http://obozrevatel.com/blogs/63107-ukrainskij-agrosektor-na-shlyahu-reform-zdobutki-ta-perspektivi.htm

3. Володимир Панченко про перспективи розвитку української економіки. NEWSONE 20.03.2016 p. [Електронний ресурс]. - Режим доступу: https://www.youtube.com/watch?v=m4gWzIb8Mpo\&feature $=$ youtu.be

4. Brettel C., Hollifield J.F. Migration Theory: Taking Across Discilines. - New York : Routledge, 2007. -304 p.

5. Переведенцев В.И. Миграции населения в СНГ: опыт прогноза. - М. : Полис, 2005. - 167 с.

6. Курунова Ю.О. Міжнародна міграція робочої сили як чинник економічного розвитку країн (на прикладі міграційних потоків між ЄС і Україною): дис. ... канд. екон. наук : 08.00.02 / Ю.О. Курунова; МОН України; Одеський національний ун-т ім. І.І. Мечникова. - Одеса, 2015. - 216 с.

7. Hein de Haas. Migration transitions: a theoretical and empirical inquiry into the developmental drivers of international migration / Hein de Haas // International Migration Institute. - 2010. - 24. - 49 p.

8. Hein de Haas. Migration and Development: A Theoretical Perspective / Hein de Haas.- Germany, Bielefeld : Center for Interdisciplinary Research, 2010. - $41 \mathrm{p}$.

9. Массей Д. Синтетическая теория международной миграции / Д. Массей // Мир в зеркале международной миграции. Сер. : Международная миграция населения: Россия и современный мир. - М. : Макс Пресс, 2002. - Вып. 10.- С. 161-174.

10. Castles, Stephen and Miller, Mark J. The Age of Migration:International Population Movements in the Modern World.- Palgrave Macmillan; 3-ed edition.-2003.- 352 p.

11. Дембіцька А.В. Причини та основні мотиви міграції робочої сили в світі та Україні / А.В. Дебіцька // Вісник Чернівецького торговельно-економічного інституту. - 2012. - Вип. 4. - С. 71-76. 
12. Макаренко І.П. Еволюційні передумови виникнення голоду в періоди соціально-економічних криз / І.П. Макаренко // Демографія і соціальна економіка №1(21) 2014. - С. 180-191. - doi: $10.15407 /$ dse2014.01.180

13. Блум Дэйвид Э., Кэннинг Дэйвид. Подъемы, спады и их отголоски: как крупнейший в истории демографический переворот сказывается на глобальном развитии / Дэйвид Э. Блум, Дэйвид Кэннинг // Финансы \& развитие. - сентябрь 2006. - Вып. 43, № 3. - С. 8-13.

14. Рівень життя населення України / [За ред. Л.М. Черенько; НАН України. Ін-т демографії та соц. дослідж., Держкомстат України]. - К. : Консультант, 2006. - 428 с.

15. Сценарно-поетапна модель валютно-фінансових криз: системи індикаторів / І.П. Макаренко, В.С. Найдьонов, О.Г. Рогожин, Я.В. Петраков. - К. : Профі, 2014. - 184 с.

16. Рогожин О.Г. Соціально-економічний механізм формування медико-демографічної ситуації в селах України / О.Г. Рогожин. - К. : Інститут демографії та соціальних досліджень НАН України, Інститут проблем національної безпеки РНБО України, 2009. - 200 с.

17. Рогожин О.Г., Макаренко І.П. Інноваційно ефективний соціальний капітал: питання ідентифікації та вимірювання / О.Г. Рогожин, І.П. Макаренко // Демографія та соціальна економіка. 2013. - № 2 (20). - C. 82-92. - doi: 10.15407/dse2013.02.082

\section{REFERENCES}

1. Ukraina vse bolshe prevraschaetsa v agrarnuyu stranu [Ukraine Turns into Agrarian Country More and Mmore]. (n.d.). iee.org.ua Retrieved from http://iee.org.ua/ru/prog_info/35382/ [in Russian].

2. Pavlenko, O. Ukrainskiy agrosector na shliahu reform: zdobutki ta perspektivi [Ukrainian Agrarian Sector on the Way of Reforms: Achievements and Prospects]. (n.d.). obozrevatel.com Retrieved from http://obozrevatel.com/blogs/63107-ukrainskij-agrosektor-na-shlyahu-reform-zdobutki-ta-perspektivi. htm [in Ukrainian].

3. Volodimir Panchenko pro perspektivi rozvitku ukrainskoi ekonomiki [Volodimir Panchenko About the Prospects of the Ukrainian Economy Development] (2016). youtube.com. Retrieved from https://www. youtube.com/watch? $\mathrm{v}=\mathrm{m} 4 \mathrm{gWzIb} 8 \mathrm{Mpo} \&$ feature $=$ youtu.be [in Ukrainian].

4. Brettel, C. \& Hollifield, J.F (2007). Migration Theory: Taking Across Discilines. New York: Routledge [in English].

5. Perevedencev, V.I. (2005). Migracii naselenija $v$ SNG opyt prognoza [The Migration of Population in CIS: an Attemptof Pprognosis]. Moscow. Polis [in Russian].

6. Kurunova, Yu.O. (2015). Mizhnarodna mihratsiia robochoi syly iak chynnyk ekonomichnoho rozvytku krain (na prykladi mihratsijnykh potokiv mizh YeS i Ukrainoiu) [Labour Force Migration as a Factor of Economic Development (the Instance of EC-Ukraine Migration Flows)]. Extended abstract of candidate's thesis. MON Ukrainy; Odes'kyj natsional'nyj universytet imeni I.I. Mechnykova. Odesa. [in Ukrainian].

7. Hein de Haas (2010). Migration transitions: a theoretical and empirical inquiry into the developmental drivers of international migration, Vol. 24. International Migration Institute [in English].

8. Hein de Haas (2010). Migration and Development: A Theoretical Perspective. Germany, Bielefeld: Center for Interdisciplinary Research [in English].

9. Massej, D. (2002) Synthetical Theory of International Migration. The World in the Mirror of International Migration: International Migration: Russia and Present World. (Vol 10, 161-174). Moscow: Maks Press, [in Russian].

10. Castles, Stephen and Miller, Mark, J. (2003) The Age of Migration: International Population Movements in the Modern World. Palgrave Macmillan (3d ed) [in English].

11. Dembits'ka, A.V. (2012) Prychyny ta osnovni motyvy mihratsii robochoi syly v sviti ta Ukraini [Reasons and Main Motives of Labour Force Migration in the World and Ukraine]. Visnyk Chernivets'koho torhovel'no-ekonomichnoho instytutu - Bulletin of Chernivtsi Trade and Economic Institute, 4, 71-76. [in Ukrainian].

12. Makarenko, I.P (2015). Evoliutsijni peredumovi viniknenia golodu v periodi socialno-ekonomichnikh kriz [Evolutional Pre-Conditions of Famine Occurrence in Periods of Socio-Economic Crise]. Demohrafiia ta sotsialna ekonomika - Demography and social economy, 1(21), 180-191. doi: 10.15407/ dse2014.01.180 [in Ukrainian]. 
13. Blum, D. Je. \& Kjenning, D. (2006) Pod'emy, spady i ih otgoloski: kak krupnejshij v istorii demograficheskij perevorot skazyvaetsja na global'nom razvitii [Booms, Recessions and it's Echos: How the Greatest in History Democraphic Revolution is Marked on Global Development]. Finansy \& razvitie Finances\& Development, 43, 3, 8-13. [in Russian].

14. Cheren'ko, L.M. (Eds.). (2006). Riven' zhyttia naselennia Ukrainy [Living Standards of Ukrainian Population]. NAN Ukrainy. In-t demohrafii ta sots. doslidzh., Derzh. Kom. statystyky Ukrainy. Kyiv: Vydavnytstvo Konsul'tant [in Ukrainian].

15. Makarenko, I.P., Naydionov, V.S., Rogozhyn, O.G. \& Petrakov, J.V. (2014) Stsenarno-poetapna model' valiutno-finansovykh kryz: systemy indykatoriv [Financial Crisis Development Model: Systems of Indicators]. Kyiv: NVC Profi [in Ukrainian].

16. Rogozhyn, O.G. (2009). Sotsial'no-ekonomichnyj mekhanizm formuvannia medyko-demohrafichnoi sytuatsii v selakh Ukrainy [Social and Economic Mechanism of Formation of Medical-Demographic Situation in Ukrainian Countryside]. Kyiv: Institute for Demography and Social Studiesof the National Academy of Sciences of Ukraine, Institute of National Security Problems National Security and Defense Council of Ukraine [in Ukrainian].

17. Rogozhyn, O.G. \& Makarenko, I.P. (2013) Innovatsijno efektyvnyj sotsial'nyj kapital: pytannia identyfikatsii ta vymiriuvannia [Inovative Social Capital: The Problems of Identification and Measuremen]. Demohrafiia ta sotsialna ekonomika - Demography and social economy, 2(20), 82-92. doi: 10.15407/ dse2013.02.082 [in Ukrainian].

Стаття надійшла до редакції журналу 22.08.2016. 